\title{
EDUKASI GERAKAN PENGELOLAAN LINGKUNGAN
}

\author{
Oleh
}

\section{ELI FADILAH}

\section{Latar Belakang}

Lingkungan hidup merupakan kesatuan ruang dengan semua benda, daya, keadaan, dan makhluk hidup, termasuk manusia dan perilakunya, yang mempengaruhi alam itu sendiri, kelangsungan perikehidupan, dan kesejahteraan manusia serta makhluk hidup lain.(Manik, 2018) Perlindungan dan pengelolaan lingkungan hidup adalah upaya sistematis dan terpadu yang dilakukan untuk melestarikan fungsi lingkungan hidup dan mencegah terjadinya pencemaran dan/atau kerusakan lingkungan hidup yang meliputi perencanaan, pemanfaatan, pengendalian, pemeliharaan, pengawasan, dan penegakan hukum.(Manik, 2018)

Pendidikan lingkungan hidup merupakan proses membangun masyarakat yang sadar dan peduli terhadap lingkungan yang memiliki pengetahuan, ketrampilan, sikap dan tingkah laku, motivasi serta komitmen untuk bekerja sama, baik individu maupun bersama-sama sebagai pemecahan masalah lingkungan kini dan yang akan datang.(Maghfur, 2010)

Pendidikan Lingkungan Hidup berfokus pada: (Kepedulian masyarakat., Pengetahuan dan pemahaman tentang lingkungan hidup dan tantangannya., Perubahan perilaku terhadap lingkungan hidup dan mengembangkan peningkatan kualitas lingkungan hidup, Antisipasi terjadinya permasalahan lingkungan hidup, Partisipasi untuk menerapkan pengetahuan dan keahlian terkait program lingkungan hidup.(Maghfur, 2010)

\section{Hasil Kajian}

Kerusakan lingkungan akibat ulah manusia berdampak pada keselamatan dan kesehatan pada manusia itu sendiri. Keruskaan lingkungan baik didarat, laut maupun udara akibat tangan-tangan manusia yang tidak bertanggung jawab. 
Situasi lingkungan di provinsi Banten misalnya terjadi penurunan kualitas air sungai Cibanten(Hayat \& Kurniatillah, 2021) dan sungai Cidanau melebihi baku mutu lingkungan yang ditetapkan oleh pemerintah.(Hayat, 2020) Penanganan limbah medis berbahaya,(Hayat, 2015) Berdampak pada kejadian penyakit menular di masyarakat dan penyakit akibat berkembangbiaknya vektor nyamuk malaria.(Hayat \& Kurniatillah, 2009)

Situasi ini diperlukan usaha-usaha yang bersifat nyata dilakukan oleh pemerintah bersama masyarakat melalui pendidikan lingkungan hidup. Gerakan hidup bersih dan sehat (PHBS).(Hayat, Nurdiawati, et al., 2021) Kegiatan terkait perubahan perilaku melalui sarana-sarana media teknologi,(Hayat, 2021) peran penting keluarga,(Hayat, Arifiati, et al., 2021) perubahan perilaku melalui penataan pengetahuan, sikap dan perilaku manusia. (Hayat, 2012)

\section{Kesimpulan}

Pendidikan lingkungan hidup merupakan proses membangun masyarakat yang sadar dan peduli terhadap lingkungan yang memiliki pengetahuan, ketrampilan, sikap dan tingkah laku, motivasi serta komitmen untuk bekerja sama, baik individu maupun bersama-sama sebagai pemecahan masalah lingkungan kini dan yang akan datang.

\section{Referensi:}

Hayat, F. (2012). Pengaruh predisposing factor, Enable factor, Reinforcing factor terhadap praktik keselamatan kerja pada tenaga kesehatan dalam pengelolaan limbah medis padat di Puskesmas Wilayah Kota Cilegon tahun 2011. In Unpad Repository. Unpad.

Hayat, F. (2015). Analisis faktor pengelolaan limbah medis padat di Rumah Sakit Umum Daerah Kota Cilegon. Faletehan Health Journal, 3, 146-151.

Hayat, F. (2020). Analisis Kadar Klor Bebas (Cl2) dan Dampaknya Terhadap Kesehatan Masyarakat di Sepanjang Sungai Cidanau Kota Cilegon. Jurnal Kesehatan Masyarakat Mulawarman (JKMM), 2(2), 64-69.

Hayat, F. (2021). THE EFFECT OF EDUCATION USING VIDEO ANIMATION ON ELEMENTARY SCHOOL IN HAND WASHING SKILL. Acitya: Journal of Teaching and Education, 3(1), 44-53.

Hayat, F., Arifiati, N., \& Permatasari, T. A. E. (2021). Peran Dukungan Suami dan Faktor Lainnya terhadap Pemanfaatan Pelayanan Gizi oleh Ibu Hamil 
dengan Risiko Kurang Energi Kronis (KEK). Jurnal Keperawatan Silampari, 5(1), 125-133.

Hayat, F., \& Kurniatillah, N. (2009). Situasi Malaria di Kabupaten Lebak. Kesmas: Jurnal Kesehatan Masyarakat Nasional (National Public Health Journal), 3(6), 259-263.

Hayat, F., \& Kurniatillah, N. (2021). Microbiological and Water Quality Status of Cibanten River. The First International Conference on Social Science, Humanity, and Public Health (ICOSHIP 2020), 198-200.

Hayat, F., Nurdiawati, E., \& Kurniatillah, N. (2021). EDUKASI GERAKAN PEMBERANTASAN NYAMUK (PSN) DEMAM BERDARAH PADA ANAK USIA SEKOLAH DASAR DI KECAMATAN JAWILAN KABUPATEN SERANG.

Maghfur, M. (2010). Pendidikan lingkungan hidup dan masa depan ekologi manusia. Forum Tarbiyah, 8(1), 57-71.

Manik, K. E. S. (2018). Pengelolaan lingkungan hidup. Kencana. 